\title{
Revisiting the contingency theory: dissection of entrepreneurial orientation elements in retail franchisee performance
}

\author{
Samantha Naidu, Gurmeet Singh and Jashwini Narayan \\ School of Business and Management, The University of the South Pacific, Suva, Fiji
}

Revisiting the contingency theory

\begin{abstract}
Purpose - This study aims to analyze how various contingencies within the contingency theory influence the entrepreneurial orientation (EO) elements and performance of retail franchisees in a South Pacific Island nation. Design/methodology/approach - This study employs a quantitative approach of data collection from 203 managers in a total of 89 retail franchise outlets. Convenience and snowball sampling techniques were used with data analysis through SPSS AMOS and covariance-based structural equation modelling (CB-SEM).

Findings - The results confirmed that technology, innovation and promotion; competitive edge and value co-creation; high return opportunity capitalization; and empowerment and support influenced franchisee performance, while responsive customer focused leadership and competitor knowledge proved to be insignificant. The findings supported EO's influence on both financial and non-financial indicators, with greater influence on financial indicators. The result revealed that $\mathrm{EO}$ accounts for partial impact on franchisee performance, while the remaining impact could be attributed to organization and environment contingencies. Originality/value - The study proposes a novel context of EO in franchising, where we dissect key elements within the $\mathrm{EO}$ dimensions. It also adds to the extant literature on how the broader context of environmental and organizational factors termed as "strategic fit" affects entrepreneurial franchisee performance.
\end{abstract}

Keywords Contingency theory, Entrepreneurial orientation, Franchisees, Performance, Retail, Fiji

Paper type Research paper

\section{Introduction}

Franchising contributes meaningfully to the performance of the economy. In the past few decades, franchising has turned into one of the most popular business practices in many countries (Croonen and Brand, 2015; Song et al., 2019) as it can contribute to economic development (Calderon-Monge et al., 2019; Rodriguez-Gutierrez et al., 2015). A report by the International Franchise Association (2021) revealed that franchising has a compelling relationship with the economy, particularly the USA, which is one of the leading countries that has a developed and well-structured franchise system. For example, the report revealed that in 2020, franchised businesses contributed US $\$ 670 \mathrm{bn}$ of economic output to the US economy and represented $3 \%$ of the total nominal gross domestic product (GDP). The report further stated that the projected economic output for 2021 is US $\$ 780 \mathrm{bn}$, with total nominal GDP increasing to $7 \%$.

The franchise industry is also responsible for creating huge opportunities for small business ownership and millions of jobs for employees. The International Franchise Association (2021) anticipates that franchise employment will add approximately 800,000 jobs to the US market by hiring 8.3 million workers by the end of 2021. Franchisees have helped workers secure jobs through relevant business skills and career progression opportunities, which generate economic stability (International Franchise Association, 2021). Thus, franchisees have become an interesting area of study.

Franchisees operate in an increasingly competitive environment where entrepreneurial activity is likely to increase. Entrepreneurial activities have been examined as an antecedent

Declaration of interest: none.
Received 31 March 2021 Revised 26 May 2021 Accepted 26 June 2021 
of growth, competitive advantage and superior performance (Tajeddini et al., 2020). The link between franchisees and entrepreneurial orientation (EO) is evident in extant literature (Dada et al., 2015; Watson and Dada, 2017). EO could possibly be a critical condition for the success or failure of the franchise system (Gupta and Sebastian, 2017; Rosado-Serrano et al., 2018). $\mathrm{EO}$ is considered one of the significant resources that helps an organization to pursue innovative ways to improve revenue streams, enhance possibilities of success and utilize organizational resources effectively (Raju and Phung, 2019).

Despite franchisees' contribution to economic development, franchisees are often faced with fluctuations in the economic environment, leading to a short and volatile life where many franchisees are unable to achieve sustainable growth (Croonen et al., 2016). The issue of "fit" arises between EO and franchisee performance, in that franchisees have to deal with organization and environment contingencies. Franchisees have to adapt, change and align their business strategies to these contingencies to survive (Croonen et al., 2016). Prior studies have, to a lesser degree, been concerned with investigating how performance is affected by fit (Romero-Silva et al., 2018).

The discussion above sheds light on several gaps in existing research related to EO and franchisee performance. The present study aims to address these gaps and makes theoretical contributions as follows. While there is a sizable body of theoretical and empirical work produced on EO, dissection of its individual elements remains under-explored (Colla et al., 2020). In fact, although it is widely accepted that EO improves firm performance, scholars have advised that particular attention should be placed on the context (Asgharian et al., 2021). In this research, we explore a novel context of EO in franchising, where we dissect key elements within EO dimensions (innovativeness, proactiveness, risk-taking, competitive aggressiveness and autonomy). The key elements being technology, innovation and promotion (TIP); competitive edge and value co-creation (CEVC); high return opportunity capitalization (OC); responsive customer-focused leadership and competitor knowledge (CFLCK); and empowerment and support (ES). We also argue that preceding studies (Alon et al., 2017; Giudici and Reinmoeller, 2013; Lafontaine and Slade, 2014) have considered single moderators, mainly environment factors or organizational factors' effect on franchisee performance. It is not clear how the broader context of environmental and organizational factors termed as "strategic fit" affects entrepreneurial franchisee performance. This study, therefore, has sought to conceptualize the moderation effect of environment and organization contingencies on $\mathrm{EO}$ and franchisee performance.

The next section reviews the literature on franchisee performance and EO elements followed by hypotheses development. Research methodology is then discussed, and thereafter, research results are presented. The paper concludes with several study implications, limitations and future research directions.

\section{Literature review and theoretical background \\ 2.1 Franchising and entrepreneurial orientation}

Franchising is "a strategy for cloning a business through the replication of proven business and management systems" (Hoy et al., 2017, p. 1). Franchisees are granted the right to operate the business in a prescribed manner, within a specified geographic area, in return for royalty contributions and/or other fee payments (Watson et al., 2020). Although franchisees are independent owners that exhibit entrepreneurial behaviours, the extent to which franchisees can be deemed entrepreneurial is still debatable (Watson et al., 2020; Watson and Dada, 2017). Further, $\mathrm{EO}$ is "an attribute of management style that supports change and activities related to exploiting different forms of innovation and creation of superior customer value (Tajeddini and Trueman, 2016, p. 573). As such, EO has been examined as an antecedent of growth, competitive advantage and superior performance (Tajeddini et al., 2020). Hence, the study of franchisees provides an interesting context to explore the impact of $\mathrm{EO}$ on franchisee performance. 


\subsection{The contingency theory}

The foundations of the contingency theory can be found in the early organizational theory literature (Galbraith, 1977; Lawrence and Lorsch, 1967; Pugh et al., 1968; Van de Ven, 1976; Van de Ven and Delbecq, 1974). The contingency theory suggests that contextual factors affect the way a business unit is organized, which in turn affects the performance of a company (Weill and Olson, 1989). Thus, certain ways of organising a business unit will produce better performance results when dealing with certain contextual factors, producing what is called a "good fit" (Romero-Silva et al., 2018; Williams et al., 2017).

The notion of fit is central in the field of the contingency theory, as it suggests that there are certain organizational structures and practices, i.e. business processes and policies, which are more suited to particular organizational environments (Romero-Silva et al., 2018). Therefore, organizations seek to improve their performance by improving fit and alignment with a set of contingencies and the changing external environment (McAdam et al., 2019). This process of fit is viewed as a dynamic and ongoing process especially in fast-moving business environments (Daft et al., 2010; Donaldson, 2006).

The contingency theory is especially useful when there is a lack of an established overarching theoretical framework (De Clercq et al., 2014; Simpson et al., 2012), with an emphasis on contextually grounded approaches based on contingency fit rather than a single best way to manage an organization (Donaldson, 2006). The contingency theory has been used in sectors like manufacturing (Romero-Silva et al., 2018), small and medium-sized enterprises (SMEs) (McAdam et al., 2019) and even franchising (Croonen and Broekhuizen, 2019; Roberts et al., 2020) with different focus areas (e.g. customer relationship management, operations management, quality management, franchisor-franchisee relationships, etc.). Prior studies have, to a lesser degree, been concerned with investigating how performance is affected by fit (Romero-Silva et al., 2018).

The contingency theory is suitable for the present study for a key reason. It depicts an environment-structure-performance relationship for most organizations (Williams et al., 2017). This enables us to conceptualize the relationship between $\mathrm{EO}$ elements and franchisee performance, and how potential contingencies affect the relationship. The present study, therefore, examines fit in terms of organization contingencies and how franchisees cope with the environment to attain certain performance levels.

\section{Conceptual framework and hypotheses development}

Franchisees bring financial capital, knowledge of geographic locations and labour markets to the system (Tsung-Chi et al., 2014). A franchisee must have better knowledge and understanding of its local business environment, as well as understand the needs of consumers and the potential risks that can be minimized as a consequence of this familiarity (Colla et al., 2019; Ghantous and Das, 2018). Since the five EO dimensions, namely, innovativeness, proactiveness, risk-taking, competitive aggressiveness and autonomy have been studied (e.g. Rosado-Serrano et al., 2018; Watson and Dada, 2017), in relation to franchisee performance, this study examines the key elements within the five dimensions in terms of: (1) TIP, (2) CEVC, (3) high return OC, (4) responsive CFLCK and (5) ES.

\subsection{Technology, innovation and promotion (TIP)}

TIP is a key element of EO through which many firms pursue and promote new opportunities (Anjum et al., 2018, 2019). TIP is built on current knowledge and skills that the workforce possesses and takes many forms such as conception of a new product, use of a new technological system and solutions to adapt to local market conditions (Khan et al., 2020). Some studies have discussed the influence of innovation on firm performance. For instance,
Revisiting the contingency theory 
Harel et al. (2020) found that managers in small businesses implement innovation promotion through internal processes of collaboration and knowledge transfer, and in creating an organizational culture that promotes innovation. Colla et al. (2019) attributed increase in firm performance to technological innovation invested in the business. Similarly, Kim et al. (2018) found innovation (i.e. technological and organizational) as drivers of market and ecoperformance in the food service industry. Hence, we propose the following hypothesis:

H1a. Technology, product innovation and promotion positively influence franchisee performance.

\subsection{Competitive edge and value co-creation (CEVC)}

A unique competitive edge enables firms to capture new market opportunities, ensuring that firms are always ahead of competitors and able to respond to market challenges (Baah et al., 2020). In other words, this element of EO promotes opportunity identification, which may increase market share and thus lead to value co-creation for firms (Jelenc et al., 2016). Value cocreation involves firms choosing competitive strategies to enhance customer engagement, approval, loyalty and happiness (Chathoth et al., 2016). Hence:

$H 1 b$. Unique CEVC positively influences franchisee performance.

\subsection{High return opportunity capitalization (OC)}

High return OC denotes organizational decision-making in an environment with high degrees of uncertainty and changing customer needs where firms explore risks (Dwivedi and Weerawardena, 2018; Seth et al., 2020). To achieve organizational innovation and growth strategies, organizations may invest in high-risk opportunities by making decisions amidst uncertainty and substantial resource commitment, without considering the consequences of strategic decisions and behaviours (Mishra and Mishra, 2019). Accordingly, we propose the following hypothesis:

H1c. Capitalizing on opportunities of high returns positively influences franchisee performance.

\subsection{Responsive customer-focused leadership and competitor knowledge (CFLCK)}

A responsive customer focused strategy is crucial in fast-changing environments and assists performance in some contexts (e.g. banks) (Stambaugh et al., 2020). Organizations that are focused on being responsive to customer needs and market conditions exchange market information between different departments. This creates value for the customer and, at the same time, differentiates the organization from its competitors (Murillo Oviedo et al., 2020). For instance, hotel management requires flexibility and customer responsiveness to deal with increasingly demanding customers and competitiveness of the market (Nazarian et al., 2017). Thus, we propose the following:

H1d. Responsive CFLCK positively influences franchisee performance.

\subsection{Empowerment and support (ES)}

ES is considered important entrepreneurial motivations and affords organizational members the freedom and flexibility to develop and perform entrepreneurial initiatives (Dada, 2018). In that, the level of management flexibility within the outlet and the extent of empowerment to make business decisions directly impacts business performance. Previous research (Hoy et al., 2017) highlighted that if franchisees receive trust and support from their franchisor, 
they will engage in entrepreneurial behaviour that is beneficial to the system. Thus, we propose that:

H1e. ES positively influences franchisee performance.
Revisiting the contingency theory

\subsection{Entrepreneurial orientation and performance}

Franchisee performance has been frequently positively related to EO dimensions in prior studies (Coulthard, 2017; Khan et al., 2020). EO is "underpinned by distinct but intertwined elements, which together influence the extent of entrepreneurial focus within an organization" (Martin and Javagi, 2016, p. 4). Further, EO is viewed as either a unidimensional or multidimensional construct, where the former is viewed as a sum of EO elements, and the latter where each element in EO will show a different relationship with organizational performance (Nuvriasari et al., 2020). Several researchers suggest treating EO as a multidimensional concept. Therefore, we intend to examine the relationship between EO elements and performance, and propose the following:

H2a. EO has a positive influence on franchisee performance.

$H 2 b$. EO, a multidimensional concept, has greater influence on franchisee performance.

What is important is to consider the potential link between EO and firm performance. Performance measurement is crucial for all companies because it helps in knowing the level of success or failure of all company activities (Nuvriasari et al., 2020). It is multidimensional in nature, i.e. both the financial and non-financial measures need to be considered in a study. Financial measures focus on short-term business goals and solutions, e.g. profit figures, while non-financial measures are more strategic in the long term e.g. customer portfolio (Mashovic, 2018). Hence, the present study proposes the following hypotheses:

H3a. EO has a positive influence on key financial indicators.

$H 3 b$. EO has a positive influence on key non-financial indicators.

\subsection{Organization and environment contingencies}

Finally, in line with the contingency theory, we consider the moderation hypothesis to investigate how the relationship between EO and firm performance is contingent on organization and environment factors (Escamilla-Fajardo et al., 2018). In today's globalized, changing and uncertain environments, companies of all types and contexts must evolve from a focus on internally owned and controlled resources to a focus that is open to external complementarities (Aulakh et al., 2016). For instance, organizational culture affects organizational behaviour and determines how an organization relates to its external environment (Otache and Mahmood, 2015). Prior studies (Buli, 2017) revealed that integrating EO into the operation of SMEs contributes to superior performance, which in turn enables them to thrive in institutionally complex and economically turbulent environments. Thus, we propose that:

H4. Organization and environment contingencies influence EO and performance relationship of franchisees.

Based on the literature and theoretical background review, a conceptual model is formulated that comprises four hypotheses. Figure 1 depicts the hypothesized relationships of the five EO elements and franchisee performance. 


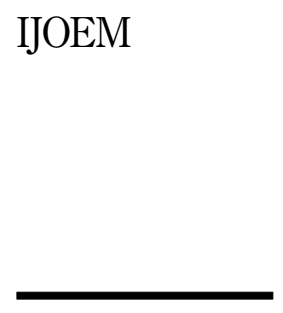

Figure 1.

Conceptual model

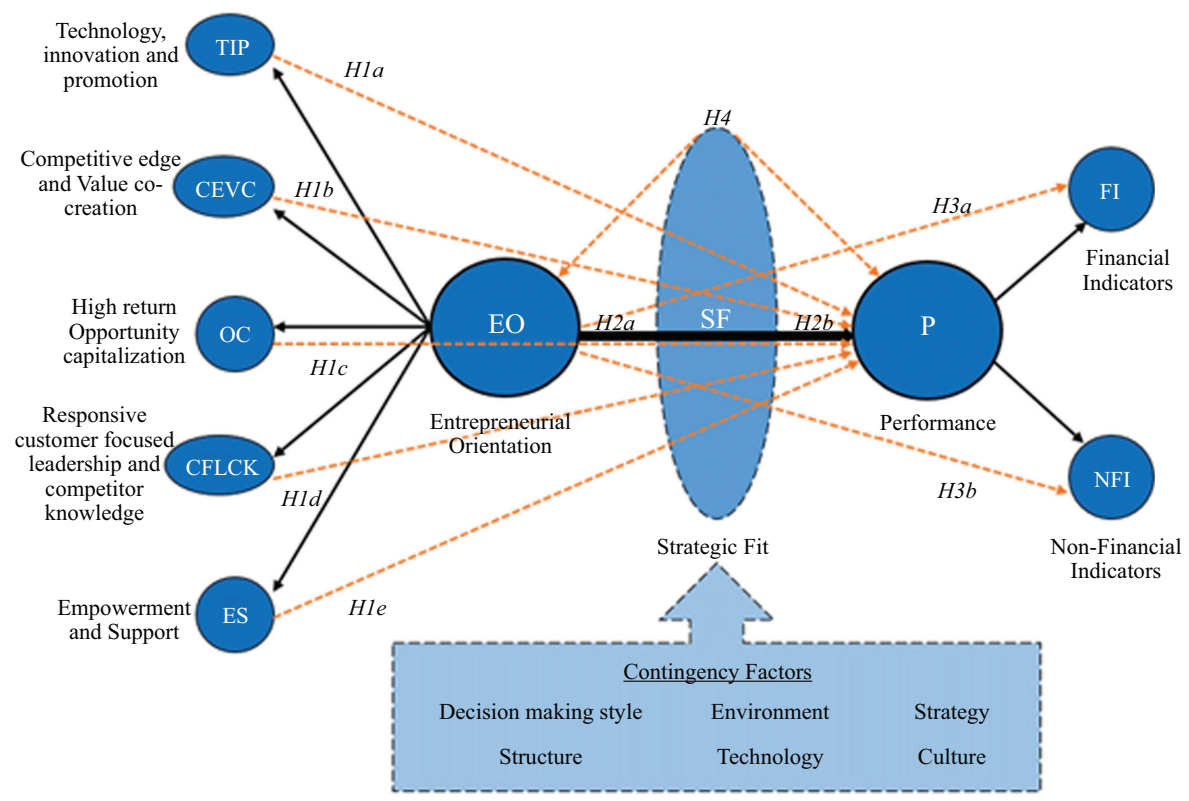

\section{Research methodology}

\subsection{Participants and procedure}

This study aims to analyze the contingencies that influence EO elements and performance of retail franchisees in Fiji. Fiji is a developing island nation in the South Pacific Island region. This study used questionnaires to collect data, with the target population being managers at different managerial levels of retail franchisees. The unit of analysis in this empirical investigation is managers because they have better knowledge of their franchisee's performance and how EO elements are reflected in franchisee activities. Franchisees sampled within the retail sector were generally representative of different industry categories, including restaurants (e.g. fast food, wine and dine, food/beverage), hotels, store retailing (e.g. supermarkets), personal services (e.g. hair and beauty), pest control services, transport and vehicle services (e.g. car hire), oil companies/gasoline service stations, automobile dealerships, soft drink bottlers and business and communication services. Hence, managerial level and industry category were controlled in this study, similar to several previous studies (e.g. Andersen and Dejoy, 2011), to increase the generalizability of the findings.

Due to the absence of a franchise body or any other entity that records franchisee data in Fiji, the researchers drew a list of franchisees operating in Fiji that were known to them. Using the convenience and snowballing technique (Pentina et al., 2016), franchisees in the greater Suva area were visited first, as these were conveniently located for the researchers. Franchisee outlets within the Western and Northern divisions were visited next. Participants were then requested to provide names of other retail franchisees within their networks that were not previously known to the researchers (Browne, 2005). This snowballing technique assisted in increasing sample size, given that franchisee numbers are low in Fiji. The use of both convenience and snowballing techniques have been used in previous studies (e.g. Brownhilder, 2016) on EO and franchisees.

Upon receipt of telephone and email confirmation and consent to participate (Tandon et al., 2020), questionnaires were physically distributed to managers at various managerial levels in retail franchisees. Prior ethics clearance was also taken from the University of the South 
Pacific. A pilot study was then carried out with 20 franchisee managers in Suva, to test for clarity and understandability of the survey instrument. All pilot study participants understood the content and structure of the questionnaire and filled them appropriately. Thus, no changes were made to the questionnaire, and distribution continued for other franchisees. Participation was voluntary without any monetary incentive provided, and participants were assured complete anonymity and confidentiality of their responses (Farooq et al., 2021). The pilot study questionnaires were incorporated in the final sample as they were deemed valid and useable for the research. Also, there were no missing data as all filled questionnaires were screened after conducting the survey at every franchisee outlet. The aforementioned procedures have ensured a high level of rigor during the data collection phase. Data collection was done in Fiji from January to July 2019.

\subsection{Measures}

The measurement items employed in this study were adopted and revised from extant literature that included: TIP (Anjum et al., 2018, 2019), CEVC (Chathoth, et al., 2016; O'Cass and Wetzels, 2018), high return OC (Dada et al., 2015; Evanschitzky et al., 2017) responsive CFLCK (Watson et al., 2019), ES (Lumpkin et al., 2009), firm performance in terms of financial indicators (Dada and Watson, 2013) and non-financial indicators (Grunhagen et al., 2014) and organization and environment contingencies (Lumpkin and Dess, 1996). All scale items were measured through a five-point Likert scale (as used in recent studies, e.g. Bhutto et al., 2020; Farooq et al., 2021; Tandon et al., 2020), ranging from "strongly disagree (1)" to "strongly agree (5)". A five-point Likert scale was used as it increases the response rate and response quality, and reduces participants' frustration levels (Babakus and Mangold, 1992; Sachdev and Verma, 2004).

\subsection{Data analysis}

SPSS and AMOS (V26) were used to perform the data analysis, and covariance-based structural equation modelling (CB-SEM) was used (as discussed by recent studies, e.g. Kaur et al., 2021; Talwar et al., 2020a, b) to test the hypothesized relationships. Following the twostep method, we first used the confirmatory factor analysis (CFA) to analyze the measurement model and assess the reliability and validity of the data before proceeding to study the structural path to test the proposed hypotheses (Cheah et al., 2020; Homburg et al., 2010; Luqman et al., 2021). We conducted moderation analysis in SPSS.

This study collected 203 responses from managers in a total of 89 retail franchise outlets in Fiji. A response rate of $95.5 \%$ was achieved. The approximate completion time for the questionnaire was $10 \mathrm{~min}$. Before analysis, we checked the data for missing values and outliers, of which none was found (Bhutto et al., 2020). Suitability of data for SEM is an important consideration. The estimation method of maximum likelihood used for SEM assumes multivariate normality of the observed data (Talwar et al., 2020a, b). Confirmation of normality of data was obtained by examining the kurtosis and skewness values, which also declared that all data scores were unbiased, efficient and within the specified range of normality. Variance inflation factors and tolerance values confirmed the absence of multicollinearity issues among the constructs (Hair et al., 2020; Talwar et al., 2020a, b).

\subsection{Demographic profile}

The gender distribution of managers in franchisees shows that data are more skewed towards males $(63.1 \%)$ than females $(36.9 \%)$. This finding is consistent with other franchisee studies (Baena, 2012; Weaven et al., 2018). Majority of managers (36.9\%) are aged between 42 and 49 years, followed by 26 and 33 years $(26.6 \%)$, 34 and 41 years $(22.7 \%)$, 50 years and over $(11.8 \%)$,
Revisiting the contingency theory

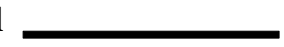


and $2.0 \%$ between 18 and 25 years. Majority of managers (30\%) earned an annual gross income of more than FJD $\$ 61,000$, followed by $22.2 \%$ earned between FJD $\$ 31,000$ and FJD $\$ 40,000$.

\section{Results}

\subsection{Common method bias}

Due to use of self-reported data, it was important to address the potential occurrence of common method bias (CMB) (Podsakoff et al., 2012). As such, Harman's single-factor test was applied to examine the data for potential threat of CMB (Tandon et al., 2020). The variance was computed to be $37.50 \%$ and was within the recommended value of $50 \%$ (Tandon et al., 2020); therefore, CMB was not a potential threat to the study.

\subsection{Measurement model}

The measurement model generated through CFA returned acceptable model fit indices $\left(\mathrm{x}^{2} / \mathrm{df}=1.82, \mathrm{CFI}=0.95, \mathrm{NFI}=0.91, \mathrm{IFI}=0.96, \mathrm{TLI}=0.95, \mathrm{PNFI}=0.79, \mathrm{PCFI}=0.82\right.$, RMSEA $=0.05$ ), in line with the recommended values (Hair et al., 2014). The reliability of the constructs was confirmed since the values of Cronbach's alpha for all constructs were greater than 0.70 . The relevant values are reported in Table 1 . Factor loading values were in the range of $0.51-0.92$, thereby exceeding the threshold limit of 0.5 (Field, 2016). We confirmed the convergent validity of all the constructs (Table 2) since the standardized path coefficient exceeded the required cut-off point of 0.4 (Hair et al., 2010). Similarly, we confirmed the discriminant validity through the following measures: (1) the co-variances between constructs were less than 0.85 (Table 3) (Blunch, 2016) and (2) the heterotrait-monotrait (HTMT) value of each pair of the construct was less than 0.9 (Table 4), as recommended (Henseler et al., 2015).

\subsection{Structural model}

Figure 2 as well as Table 5 represents the results of the structural path analysis. H1a proposed a positive influence between TIP and FP, which was supported $(\beta=0.13, p<0.05)$. $\mathrm{H} 1 \mathrm{~b}$, proposing a direct influence between CEVC and FP, was also supported $\beta=0.27$, $p<0.05$ ). Similarly, H1c proposed a positive influence between OC and FP, which was supported $(\beta=0.26, p<0.05)$. However, H1d predicting a positive influence between CFLCK and FP was not supported $(\beta=0.01, p>0.05)$. H1e, on the contrary, posited a positive influence between ES and FP, which was statistically significant $(\beta=0.89, p<0.05)$. H2 proposed a positive influence between $\mathrm{EO}$ and $\mathrm{FP}$, which was supported $(\beta=0.59, p<0.5)$. $\mathrm{H} 2$ further posited EO to have a greater influence on FP when it was observed as a multi-

Table 1. Construct reliability analysis

\begin{tabular}{llccc}
\hline Initials & Construct full name & $\begin{array}{c}\text { No. of } \\
\text { items } \\
\text { Retained }\end{array}$ & $\begin{array}{c}\text { Composite } \\
\text { mean }\end{array}$ & $\begin{array}{c}\text { Cronbach's } \\
\text { alpha }\end{array}$ \\
\hline CFLCK & $\begin{array}{l}\text { Responsive customer-focused leadership and } \\
\text { competitor knowledge }\end{array}$ & 8 & 4.494 & 0.936 \\
FI & Financial indicators & 8 & 4.448 & 0.912 \\
TIP & Technology, innovation and promotion & 7 & 4.582 & 0.931 \\
EO & Entrepreneurial orientation & 5 & 4.356 & 0.886 \\
OC & High return opportunity capitalization & 4 & 4.000 & 0.922 \\
NFI & Non-financial indicators & 4 & 4.144 & 0.868 \\
CEVC & Competitive edge and value co-creation & 4 & 4.425 & 0.857 \\
ES & Empowerment and support & 3 & 4.088 & 0.788
\end{tabular}

Note(s): The reliability of the constructs was confirmed since the values of Cronbach's alpha for all constructs were greater than 0.70 


\begin{tabular}{|c|c|c|c|c|c|c|c|c|}
\hline & & & Estimate & Standardized & $\mathrm{SE}$ & CR & $P$ & evisiting the \\
\hline CFLCK01 & $<-$ & CFLCK & 1.000 & 0.990 & - & - & - & theory \\
\hline CFLCK02 & $<-$ & CFLCK & 0.792 & 0.901 & 0.028 & 28.027 & 0.000 & \\
\hline CFLCK04 & $<-$ & CFLCK & 1.010 & 0.838 & 0.048 & 21.187 & 0.000 & \\
\hline CFLCK05 & $<-$ & CFLCK & 0.825 & 0.693 & 0.061 & 13.446 & 0.000 & \\
\hline CFLCK06 & $<-$ & CFLCK & 0.669 & 0.745 & 0.043 & 15.597 & 0.000 & \\
\hline CFLCK07 & $<-$ & CFLCK & 0.820 & 0.680 & 0.063 & 13.004 & 0.000 & \\
\hline CFLCK09 & $<-$ & CFLCK & 0.858 & 0.643 & 0.073 & 11.789 & 0.000 & \\
\hline CFLCK10 & $<-$ & CFLCK & 0.996 & 0.984 & 0.017 & 59.339 & 0.000 & \\
\hline FI01 & $<-$ & FI & 1.000 & 0.961 & - & - & - & \\
\hline FI02 & $<-$ & FI & 0.977 & 0.956 & 0.031 & 31.723 & 0.000 & \\
\hline FI03 & $<-$ & FI & 0.848 & 0.720 & 0.061 & 13.841 & 0.000 & \\
\hline FI04 & $<-$ & FI & 0.848 & 0.804 & 0.049 & 17.474 & 0.000 & \\
\hline FI05 & $<-$ & FI & 1.080 & 0.745 & 0.073 & 14.800 & 0.000 & \\
\hline FI06 & $<-$ & FI & 0.806 & 0.681 & 0.064 & 12.514 & 0.000 & \\
\hline FI07 & $<-$ & FI & 1.110 & 0.626 & 0.102 & 10.919 & 0.000 & \\
\hline FI08 & $<-$ & FI & 1.183 & 0.723 & 0.085 & 13.968 & 0.000 & \\
\hline TIP01 & $<-$ & TIP & 1.000 & 0.675 & - & - & - & \\
\hline TIP02 & $<-$ & TIP & 1.395 & 0.941 & 0.115 & 12.154 & 0.000 & \\
\hline TIP03 & $<-$ & TIP & 1.095 & 0.827 & 0.101 & 10.879 & 0.000 & \\
\hline TIP04 & $<-$ & TIP & 1.001 & 0.595 & 0.124 & 8.054 & 0.000 & \\
\hline TIP05 & $<-$ & TIP & 1.326 & 0.965 & 0.107 & 12.411 & 0.000 & \\
\hline TIP06 & $<-$ & TIP & 1.120 & 0.819 & 0.104 & 10.783 & 0.000 & \\
\hline TIP07 & $<-$ & TIP & 1.417 & 0.902 & 0.121 & 11.726 & 0.000 & \\
\hline SF01 & $<-$ & $\mathrm{SF}$ & 1.000 & 0.858 & - & - & - & \\
\hline SF02 & $<-$ & $\mathrm{SF}$ & 0.665 & 0.643 & 0.066 & 10.099 & 0.000 & \\
\hline SF03 & $<-$ & $\mathrm{SF}$ & 1.122 & 0.856 & 0.073 & 15.435 & 0.000 & \\
\hline SF04 & $<-$ & $\mathrm{SF}$ & 0.974 & 0.887 & 0.060 & 16.348 & 0.000 & \\
\hline SF05 & $<-$ & $\mathrm{SF}$ & 0.869 & 0.645 & 0.086 & 10.148 & 0.000 & \\
\hline OC01 & $<-$ & $\mathrm{OC}$ & 1.000 & 0.914 & - & - & - & \\
\hline $\mathrm{OC} 02$ & $<-$ & $\mathrm{OC}$ & 0.997 & 0.971 & 0.037 & 27.085 & 0.000 & \\
\hline OC03 & $<-$ & $\mathrm{OC}$ & 1.044 & 0.962 & 0.040 & 26.286 & 0.000 & \\
\hline OC04 & $<-$ & $\mathrm{OC}$ & 0.482 & 0.618 & 0.046 & 10.390 & 0.000 & \\
\hline NFI01 & $<-$ & NFI & 1.000 & 0.843 & - & - & - & \\
\hline NFI02 & $<-$ & NFI & 0.782 & 0.753 & 0.063 & 12.352 & 0.000 & \\
\hline NFI03 & $<-$ & NFI & 0.735 & 0.616 & 0.078 & 9.430 & 0.000 & \\
\hline NFI04 & $<-$ & NFI & 0.895 & 0.914 & 0.055 & 16.272 & 0.000 & \\
\hline CEVC01 & $<-$ & CEVC & 1.000 & 0.533 & - & - & - & \\
\hline CEVC02 & $<-$ & CEVC & 0.835 & 0.425 & 0.123 & 6.760 & 0.000 & \\
\hline CEVC03 & $<-$ & CEVC & 2.268 & 1.170 & 0.253 & 8.957 & 0.000 & \\
\hline CEVC04 & $<-$ & CEVC & 1.092 & 0.537 & 0.139 & 7.856 & 0.000 & \\
\hline ES01 & $<-$ & ES & 1.000 & 0.815 & - & - & - & \\
\hline ES02 & $<-$ & ES & 0.566 & 0.747 & 0.053 & 10.629 & 0.000 & Table 2. \\
\hline ES03 & $<-$ & ES & 0.805 & 0.743 & 0.076 & 10.580 & 0.000 & Convergent validity \\
\hline \multicolumn{9}{|c|}{ Note(s): Convergent validity of all the constructs through regression path coefficient } \\
\hline
\end{tabular}

dimensional construct. H3a, which proposed an association between EO and FI, was statistically significant $(\beta=0.55, p<0.05)$. Similarly, H3b proposed a positive influence between $\mathrm{EO}$ and NFI, which was supported $(\beta=0.38, p<0.05)$.

\subsection{Moderation analysis}

The moderation analysis involved examining the moderation effect of SF on the association between EO and FP, and is presented in Figure 2. The analysis was performed through SEM and further supported by SPSS. To begin with, the effect of a moderating latent factor, the 


\section{IJOEM}

\begin{tabular}{lllrrrr}
\hline & & & Estimate & SE & CR & $P$ \\
\hline CFLCK & $<->$ & FI & 0.121 & 0.021 & 5.854 & 0.000 \\
CFLCK & $<->$ & TIP & 0.125 & 0.019 & 6.464 & 0.000 \\
CFLCK & $<->$ & SF & 0.111 & 0.023 & 4.864 & 0.000 \\
CFLCK & $<->$ & OC & 0.170 & 0.042 & 4.086 & 0.000 \\
CFLCK & $<->$ & NFI & 0.149 & 0.031 & 4.756 & 0.000 \\
CFLCK & $<->$ & CEVC & -0.035 & 0.014 & -2.544 & 0.011 \\
CFLCK & $<->$ & ES & 0.105 & 0.040 & 2.654 & 0.008 \\
FI & $<->$ & TIP & 0.083 & 0.015 & 5.483 & 0.000 \\
FI & $<->$ & SF & 0.061 & 0.019 & 3.288 & 0.001 \\
FI & $<->$ & OC & 0.175 & 0.037 & 4.793 & 0.000 \\
FI & $<->$ & NFI & 0.209 & 0.030 & 6.901 & 0.000 \\
FI & $<->$ & CEVC & 0.014 & 0.011 & 1.249 & 0.212 \\
FI & $<->$ & ES & -0.005 & 0.033 & -0.151 & 0.880 \\
ES & $<->$ & SF & 0.063 & 0.015 & 4.116 & 0.000 \\
ES & $<->$ & OC & 0.177 & 0.032 & 5.500 & 0.000 \\
ES & $<->$ & NFI & 0.100 & 0.022 & 4.542 & 0.000 \\
ES & $<->$ & CEVC & 0.044 & 0.011 & 3.913 & 0.000 \\
ES & $<->$ & ES & 0.102 & 0.028 & 3.665 & 0.000 \\
OEC & $<->$ & OC & 0.226 & 0.042 & 5.313 & 0.000 \\
OEC & $<->$ & NFI & 0.088 & 0.029 & 3.072 & 0.002 \\
OEC & $<->$ & CEVC & 0.040 & 0.014 & 2.911 & 0.004 \\
OEC & $<->$ & ES & 0.180 & 0.040 & 4.443 & 0.000 \\
OC & $<->$ & NFI & 0.235 & 0.056 & 4.202 & 0.000 \\
OC & $<->$ & CEVC & 0.124 & 0.030 & 4.108 & 0.000 \\
OC & $<->$ & ES & 0.376 & 0.077 & 4.876 & 0.000 \\
NFI & $<->$ & CEVC & -0.008 & 0.017 & -0.490 & 0.624 \\
NFI & $<->$ & ES & -0.197 & 0.054 & -3.652 & 0.000 \\
CEVC & $<->$ & ES & 0.033 & 0.023 & 1.428 & 0.153 \\
Note & $<0-V 15$ & & & &
\end{tabular}

Table 3.

Discriminant validity analysis

Note(s): Co-variances between constructs

\begin{tabular}{lcccccccc}
\hline & CFLCK & FI & TIP & EO & OC & NFI & CEVC & ES \\
\hline CFLCK & - & - & - & - & - & - & - & - \\
FI & 0.22 & - & - & - & - & - & - & - \\
TIP & 0.35 & 0.19 & - & - & - & - & - & - \\
EO & 0.20 & 0.08 & 0.09 & - & - & - & - & - \\
OC & 0.11 & 0.19 & 0.20 & 0.19 & - & - & - & - \\
NFI & 0.14 & 0.22 & 0.12 & 0.13 & 0.18 & - & - & - \\
CEVC & 0.13 & 0.12 & 0.16 & 0.07 & 0.11 & -0.002 & - & - \\
ES & 0.12 & -0.02 & 0.12 & 0.14 & 0.15 & -0.21 & -0.08 & - \\
Note(s): HTMT analysis & & & & & & & \\
\end{tabular}

composite scores for SF, as well as FP and EO were computed. This was followed by the transformation of these composite scores into $\mathrm{z}$-scores, and then establishing the interaction effect between SF and FP (SF*FP), as well as the interaction effect between SF and EO (SF*EO), as recommended (Dugard et al., 2010). Effectively, the moderation effect of SF on the relationship between $\mathrm{EO}$ and $\mathrm{FP}$ was statistically significant $(\beta=0.31, p<0.05)$. However, the effect was higher than the moderation effect of SF on the relationship between FP and EO $(\beta=0.18, p<0.05)$. Thus, the moderation effect of SF was supported. Similarly, a regression analysis was done in SPSS to further prove SF results. The value of $R$-square $\left(R^{2}=0.53\right)$ indicated that EO partially impacts FP (Table 6). The remaining impact could be attributed to 


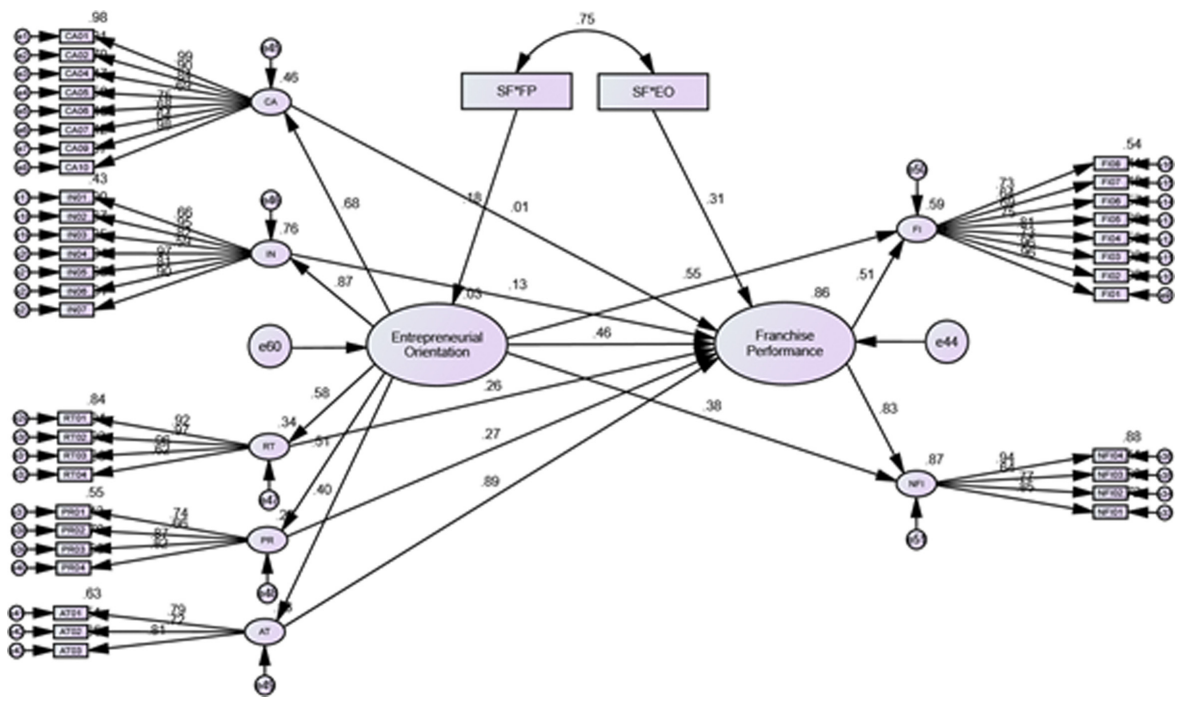

Revisiting the contingency theory

Figure 2. SEM

\begin{tabular}{lllccccc}
\hline & & & Estimate & Standardized & SE & CR & $P$ \\
\hline EO & $<-$ & SF_FP & 0.066 & 0.184 & 0.029 & 2.274 & 0.023 \\
FP & $<-$ & EO & 1.000 & 0.594 & 0.130 & 7.901 & 0.000 \\
FP & $<-$ & CFLCK & 0.006 & 0.005 & 0.109 & 0.055 & 0.956 \\
FP & $<-$ & TIP & 0.234 & 0.131 & 0.154 & 2.121 & 0.037 \\
FP & $<-$ & OC & 0.165 & 0.264 & 0.052 & 3.171 & 0.002 \\
FP & $<-$ & CEVC & 0.292 & 0.265 & 0.092 & 3.163 & 0.002 \\
FP & $<-$ & ES & 0.637 & 0.887 & 0.072 & 8.828 & 0.000 \\
FP & $<-$ & SF_EO & 0.237 & 0.309 & 0.047 & 5.007 & 0.000 \\
NFI & $<-$ & EO & 1.000 & 0.383 & 0.129 & 5.254 & 0.000 \\
FI & $<-$ & EO & 1.117 & 0.548 & 0.128 & 7.206 & 0.000
\end{tabular}

Note(s): Structural path analysis of hypothesized relationships

Table 5. Structural equation model results

\begin{tabular}{lcccc}
\hline $\begin{array}{l}\text { Model summary } \\
\text { Model }\end{array}$ & $R$ & $R$-square & Adjusted $R$-square & Std. error of the estimate \\
\hline 1 & $0.726^{\text {a }}$ & 0.527 & 0.519 & 0.63879 \\
Note(s): & a. predictors: (constant), EO. Regression analysis of the moderator SF on EO and FP
\end{tabular}

Table 6. Moderation analysis

$\mathrm{SF}$ (organization and environment contingencies). As such, H4, hypothesizing the moderation effect of SF on the association between EO and FP, was supported.

\section{Discussion, theoretical contributions and implications}

6.1 Discussion of results

As seen from the results presented in Section 5.3 and Figure 2, H1a, which proposed a positive influence between TIP and franchisee performance, was supported by the study results. 
Although TIP is a new element that we proposed within the EO dimension of innovativeness, innovativeness has previously been documented as having a positive impact on franchisee performance (Colla et al., 2019; Dada et al., 2015; Ghantous and Das, 2018). Thus, our finding is in consonance with the prior studies. The finding implies that franchisee performance can improve if franchisees introduce new products and make changes to current products to appeal better to consumers. Therefore, the EO element of TIP can be improved if franchisees channel more effort towards promoting product and service quality, and acquire new technology that this relevant in delivering quality results.

$\mathrm{H} 1 \mathrm{~b}$ posited a positive influence between unique CEVC and franchisee performance. CEVC also being a new element within the EO dimension of proactiveness has been found to impact franchisee performance in extant literature (Dada et al., 2015; Thammasane, 2018). Franchisees that possess CEVC are able to offer unique products and services. Having the right resources and technologies at the right time, which competitors may lack, will enable franchisees to create demand for their products. The aspect of value co-creation enables franchisees to forecast future product demands and make necessary changes, as well as create new policies that would assist franchisees in achieving competitive edge and improve business performance.

Similarly, H1c proposed a positive influence between OC and franchisee performance, and was supported by the findings. This finding suggests that franchisees could capitalize on opportunities yielding high returns for improved performance and franchisee satisfaction. Working with a trusted franchisor brand makes it easier for franchisees to invest in risky opportunities. Nonetheless, franchisees are likely to take calculated risks based on local market conditions, interest rates and return on investments, as depicted in previous research (Coulthard, 2017; Dada et al., 2015; Evanschitzky et al., 2017; Lopez-Fernandez and LopezBayon, 2018).

The results did not support H1d. Although there was a positive influence between CFLCK and franchisee performance, this element was not statistically significant. CFLCK being a new element within the EO dimension of competitive aggressiveness has received mixed results for the dimension in extant literature (e.g. weak association in Rauch and Frese (2006) and Rauch et al. (2009) studies; strong association in Dada et al. (2015) and Colla et al. (2020) studies). The reason for this could be attributed to CFLCK being an attitudinal and behavioural characteristic that differs in franchisees. Hence, franchisees need to be more responsive to customer needs and problem-solving. The result also implies that franchisees cannot rely on internally controlled resources alone to pursue advantageous strategies for improved firm performance. They need to strengthen collaboration with other firms to outcompete rivals.

H1e, positing that ES influences franchisee performance, was supported, in line with past studies (Colla et al., 2020; Grunhagen et al., 2014; Rauch, et al., 2009). Franchisees require ES from the franchisor in terms of carrying out business operations, e.g. what they want to sell. However, the trade-off lies in the balance between franchisor-franchisee control and how much ES is necessary for the franchisee to aid in improved business performance.

The results supported $\mathrm{H} 2$ and $\mathrm{H} 3$. $\mathrm{H} 2$ proposed a positive influence between $\mathrm{EO}$ and franchisee performance. Similarly, H3 posited a positive influence between EO and financial and non-financial indicators. These findings concur with previous studies (Chien, 2014; Coulthard, 2017; Dada et al., 2015; Dada and Watson, 2013). Franchisees need to implement EO to achieve higher performance outcomes. Despite the result indicating that franchisees focus more on financial indicators such as profits and sales turnover, to improve firm performance, non-financial indicators, such as corporate social responsibility and customer loyalty, need to be given consideration too.

Finally, our results supported the existence of the moderation effect of SF on the association between EO and franchisee performance (H4), which is a novel association that has not previously been examined. Preceding studies have considered single moderators, such as environment factors (Giudici and Reinmoeller, 2013) and organization factors 
(Chuang et al., 2012) impact on franchisee performance. The result indicates that EO accounts for partial impact on franchisee performance, while the remaining impact could be attributed to SF, inclusive of organization and environment contingencies.
Revisiting the contingency theory

\subsection{Theoretical contribution}

This study makes three key theoretical contributions. First, the study proposed five novel constructs (TIP, CEVC, OC, CFLCK and ES) within the five-dimensional EO, which influence franchisee performance. By doing so, the study extends the EO literature, focusing on the dissection of individual elements within the five-dimensional EO. Previous studies have mainly examined the conceptualization and importance of EO dimensions (Chien, 2014; Coulthard, 2017; Dada et al., 2015; Dada and Watson, 2013; Lopez-Bayon and LopezFernandez, 2016) in franchisee performance.

Second, by conceptualizing the moderation effect of SF on EO and franchisee performance, we bring forth the dynamics of the relationship between $\mathrm{EO}$ and franchisee performance, where franchisee performance is not only impacted by EO elements but also by the development of new contingent factors (organization and environment) that are country specific.

Third, research on EO and franchisee performance has mainly focused on countries where franchising is common, e.g. France, The Netherlands, the USA, Canada and Taiwan. Our study is the first to extend research on franchising in a developing country context, particularly focusing on a South Pacific Island nation, where franchisee numbers are low. Also, while there have been several studies conducted on Fiji's retail sector (Singh and Slack, 2020; Singh et al., 2021; Slack et al., 2020), this study extends the context in terms of franchising, by adding value to these locally conducted retailing research. Theory building literature argues the importance of testing instruments and models in a different context to enhance generalizability and understanding of context's influence on theories (Brown et al., 2010).

\subsection{Implications for practice}

The findings of this study will enable franchisees to better understand key elements (TIP, CEVC, OC, CFLCK and ES) within EO that can improve franchisee performance. First, our study reveals that franchisees need to focus on enablers such as technology, which will improve product and service delivery. Having appropriate technology will assist franchisees to forecast future product demands, thereby achieving greater competitive edge.

Second, our findings indicate that capitalizing on risky opportunities will yield high returns, thereby increasing franchisee performance. As such, we suggest franchisees invest in potential opportunities for business growth. However, franchisees need to make calculated decisions based on local market conditions.

Finally, our study reveals that franchisees need to develop more sustainable strategies to be more responsive to customer needs and problem-solving. Franchisees need to collaborate with other firms to attain better knowledge of their customers and competitors. By doing so, franchisees will be in a better position to respond to innovation or challenges. For instance, a quick-response strategy may provide a source of sustainable competitive advantage if imitation and substitution are difficult for competitors; however, being too quick in responding to innovation or challenges, may lead to failure of integrating important feedback from the marketplace. Therefore, franchisee performance is likely to improve when EO elements are combined with both the appropriate strategy and the right contingencies.

\section{Conclusion, limitations and directions for future research}

This study examines the influence of EO elements on franchisee performance and how this relationship is affected by several contingencies. Through the participation of 203 
respondents in the survey, this study confirmed that TIP, CEVC, OC and ES influenced franchisee performance, while CFLCK proved to be insignificant. The findings supported EO's influence on both financial and non-financial indicators, with greater influence on financial indicators. Lastly, we confirmed the moderation effect of SF on the association between $\mathrm{EO}$ and franchisee performance. The result revealed that $\mathrm{EO}$ accounts for partial impact on franchisee performance, while the remaining impact could be attributed to organization and environment contingencies.

Despite its notable contributions, this study has some limitations that must be acknowledged. First, the study primarily focused on franchisees in the Fijian market, so the findings may not be applicable to franchisees in other cultural contexts. This limited generalizability can be addressed by future researchers trying to validate the findings of this study in other cultural backgrounds and geographies (Kaur et al., 2021), using a cross-country design methodology. Second, the study collected data from the retail sector. As such, the findings of the study may not be generalizable to other sectors. However, the constructs and relationships explored in our study are relevant to other sectors, be they manufacturing, service, etc. (Bhutto et al., 2020). Future studies can, thus, replicate our model in different contexts to generate related findings. Lastly, our study is based on self-reported information, including various methodological biases and lack of information on causality. Future studies could address this limitation by adopting longitudinal and experimental research designs (Talwar et al., 2020a, b).

\section{References}

Alon, I., Madanoglu, M. and Shoham, A. (2017), "Strategic agility explanations for managing franchising expansion during economic cycles", Competitiveness Review: An International Business Journal, Vol. 27 No. 2, pp. 113-131.

Andersen, M.L. and Dejoy, J.S. (2011), "Corporate social and financial performance: the role of size, industry, risk, R\&D and advertising expenses as control variables", Business and Society Review, Vol. 116 No. 2, pp. 237-256.

Anjum, T., Ramzani, S.R. and Nazar, N. (2019), "Antecedents of entrepreneurial intentions: a study of business students from Universities of Pakistan", International Journal of Business and Psychology, Vol. 1 No. 2, pp. 72-88.

Anjum, T., Ramzani, S.R., Nazar, N., Shahzad, I.A. and Salman, S. (2018), "Entrepreneurial intention: does entrepreneurial education matter in Pakistan?", International Journal of Human Resource Studies, Vol. 8 No. 3, pp. 147-161.

Asgharian, E., Tasavori, M. and Andersén, J. (2021), "Should fast-food franchisees pursue entrepreneurial orientation?", Entrepreneurship Research Journal, Vol. ahead-of-print No. ahead-of-print, doi: 10.1515/erj-2019-0377.

Aulakh, P.S., Kundu, S.K. and Lahiri, S. (2016), "Learning and knowledge management in and out of emerging markets: introduction to the special issue”, Journal of World Business, Vol. 5 No. 51, pp. 655-661.

Baah, C., Opoku-Agyeman, D., Acquah, I.S.K., Issau, K. and Moro Abdoulaye, F.A. (2020), "Understanding the influence of environmental production practices on firm performance: a proactive versus reactive approach", Journal of Manufacturing Technology Management, Vol. 32 No. 2, pp. 266-289.

Babakus, E. and Mangold, G. (1992), "Adapting the SERVQUAL scale to hospital services: an empirical investigation”, Health Service Research, Vol. 26, pp. 767-780.

Baena, V. (2012), "Market conditions driving international franchising in emerging markets", International Journal of Emerging Markets, Vol. 7 No. 1, pp. 49-71. 
Bhutto, T.A., Farooq, R., Talwar, S., Awan, U. and Dhir, A. (2020), "Green inclusive leadership and green creativity in the tourism and hospitality sector: serial mediation of green psychological climate and work engagement”, Journal of Sustainable Tourism, Vol. ahead-of-print No. aheadof-print, pp. 1-22, doi: 10.1080/09669582.2020.1867864.
Revisiting the contingency theory

Blunch, N.J. (2016), Introduction to Structural Equation Modelling Using IBM SPSS Statistics and EQS, Sage, LA.

Brown, S.A., Dennis, A.R. and Venkatesh, V. (2010), "Predicting collaboration technology use: integrating technology adoption and collaboration research", Journal of Management Information Systems, Vol. 27 No. 2, pp. 9-54.

Browne, K. (2005), "Snowball sampling: using social networks to research non-heterosexual women", International Journal of Social Research Methodology, Vol. 8 No. 1, pp. 47-60.

Brownhilder, N. (2016), "Examining the moderating effect of environmental hostility on the entrepreneurial orientation-performance relationship", Journal of Economics and Behavioral Studies, Vol. 8 No. 6(J), pp. 6-18.

Buli, B.M. (2017), "Entrepreneurial orientation, market orientation and performance of SMEs in the manufacturing industry: evidence from Ethiopian enterprises", Management Research Review, Vol. 40 No. 3, pp. 292-309.

Calderon-Monge, E., Huerta-Zavala, P. and Ayup-Gonzalez, J. (2019), "Effects of brand-related and market signals on franchisees' entrepreneurial decisions: a multi-country panel data analysis", International Entrepreneurship and Management Journal, Vol. 15 No. 2, pp. 573-588.

Chathoth, P.K., Ungson, G.R., Harrington, R.J. and Chan, E.S. (2016), "Co-creation and higher order customer engagement in hospitality and tourism services: a critical review", International Journal of Contemporary Hospitality Management, Vol. 28 No. 2, pp. 222-245.

Cheah, J.H., Memon, M.A., Richard, J.E., Ting, H. and Cham, T.H. (2020), "CB-SEM latent interaction: unconstrained and orthogonalized approaches", Australasian Marketing Journal (AMI), Vol. 28 No. 4, pp. 218-234.

Chien, S. (2014), "Franchisor resources, spousal resources, entrepreneurial orientation, and performance in a couple-owned franchise outlet", Management Decision, Vol. 52 No. 5, pp. 916-933.

Chuang, F.M., Morgan, R.E. and Robson, M.J. (2012), "Clan culture, strategic orientation and new product performance in Chinese marketing ventures: an exploration of main and moderating effects", Journal of Strategic Marketing, Vol. 20 No. 3, pp. 267-286.

Colla, E., Ruiz-Molina, E., Chastenet De Gery, C. and Deparis, M. (2020), "Franchisee's entrepreneurial orientation dimensions and performance. Evidence from France", The International Review of Retail, Distribution and Consumer Research, Vol. 30 No. 5, pp. 538-554.

Colla, E., Ruiz-Molina, M.E., De Gery, C., Schultz, M., Deparis, M. and Lemmet, L. (2019), "Understanding franchise performance. The role of franchisees' autonomy, affective commitment to the network and innovativeness", International Journal of Retail and Distribution Management, Vol. 47 No. 7, pp. 733-751.

Coulthard, M. (2017), "The role of entrepreneurial orientation on firm performance and the potential influence of relational dynamism", Journal of Global Business and Technology, Vol. 3 No. 1, pp. 29-39.

Croonen, E.P. and Brand, M.J. (2015), "Antecedents of franchisee responses to franchisor-initiated strategic change", International Small Business Journal, Vol. 33 No. 3, pp. 254-276.

Croonen, E.P. and Broekhuizen, T.L. (2019), "How do franchisees assess franchisor trustworthiness?", Journal of Small Business Management, Vol. 57 No. 3, pp. 845-871.

Croonen, E.P., Brand, M.J. and Huizingh, E.K. (2016), "To be entrepreneurial, or not to be entrepreneurial? Explaining differences in franchisee entrepreneurial behavior within a franchise system", International Entrepreneurship and Management Journal, Vol. 12 No. 2, pp. 531-553. 
Dada, O.L. (2018), "A model of entrepreneurial autonomy in franchised outlets: a systematic review of the empirical evidence", International Journal of Management Reviews, Vol. 20 No. 2, pp. 206-226.

Dada, O. and Watson, A. (2013), "Entrepreneurial orientation and the franchise system: organizational antecedents and performance outcomes", European Journal of Marketing, Vol. 47 Nos 5/6, pp. 790-812.

Dada, O., Watson, A. and Kirby, D. (2015), "Entrepreneurial tendencies in franchising: evidence from the UK", Journal of Small Business and Enterprise Development, Vol. 22 No. 1, pp. 82-98.

Daft, R.L., Murphy, J. and Willmott, H. (2010), Organization Theory and Design, Cengage Learning, London.

De Clercq, D., Thongpapanl, N. and Dimov, D. (2014), "Contextual ambidexterity in SMEs: the roles of internal and external rivalry", Small Bus. Econ, Vol. 42, pp. 191-205.

Donaldson, L. (2006), "The contingency theory of organizational design: challenges and opportunities", in Burton, R.M., Eriksen, B., Hakonsson, D.D. and Snow, C.C. (Eds), Organization Design: The Evolving State-Of-The-Art, Heidelberg, Springer, pp. 19-40.

Dugard, P., Todman, J. and Staines, H. (Eds) (2010), Approaching Multivariate Analysis. A Practical Introduction, Routledge, NY.

Dwivedi, A. and Weerawardena, J. (2018), "Conceptualizing and operationalizing the social entrepreneurship construct", Journal of Business Research, Vol. 86, pp. 32-40.

Escamilla-Fajardo, P., Nunez Pomar, J.M. and Prado Gasco, V.J. (2018), "Does the level of competition influence the relationship between entrepreneurial orientation and service quality?", Journal of Physical Education and Sport, Vol. 18 No. 3, pp. 1306-1315.

Evanschitzky, H., Backhaus, C., Blut, M. and Woisetschlager, D.M. (2017), "Efficacy of franchisee autonomy: an examination of boundary conditions", The Customer Is Not Always Right? Marketing Orientations in a Dynamic Business World, 2011 World Marketing Congress, Reims.

Farooq, R., Zhang, Z., Talwar, S. and Dhir, A. (2021), "Do green human resource management and selfefficacy facilitate green creativity? A study of luxury hotels and resorts", Journal of Sustainable Tourism, pp. 1-22.

Field, A.P. (2016), Discovering Statistics Using SPSS, Sage, London.

Galbraith, J. (1977), Organization Design, Addison-Wesley, Reading, MA.

Ghantous, N. and Das, S. (2018), "International franchising and performance: a resource-based perspective", International Journal of Retail and Distribution Management, Vol. 46 No. 8, pp. 744-763.

Giudici, A. and Reinmoeller, P. (2013), Sensing Together: An Exploration of the Support of Network Intermediaries to Firms' and Entrepreneurs' Search for New Opportunities, Ph.D., Cranfield University, Wharley End.

Grunhagen, M., Wollan, M.L., Dada, O. and Watson, A. (2014), "The moderating influence of HR operational autonomy on the entrepreneurial orientation-performance link in franchise systems", International Entrepreneurship Management Journal, Vol. 10 No. 4, pp. 827-844.

Gupta, R. and Sebastian, V.J. (2017), "Configuration approach to strategic and entrepreneurial orientation construct and small firm growth: evidence from India", Theoretical Economics Letters, Vol. 7 No. 5, p. 1261.

Hair, J.F., Howard, M.C. and Nitzl, C. (2020), “Assessing measurement model quality in PLS-SEM using confirmatory composite analysis", Journal of Business Research, Vol. 109, pp. 101-110.

Hair, J.F., Anderson, R.E., Babin, B.J. and Black, W.C. (2010), Multivariate Data Analysis: A Global Perspective, Pearson, Upper Saddle River, NJ, Vol. 7.

Hair, J.F., Sarstedt, M., Hopkins, L. and Kuppelwieser, V.G. (2014), "Partial least squares structural equation modeling (PLS-SEM): an emerging tool in business research", European Business Review, Vol. 26 No. 2, pp. 106-121. 
Harel, R., Schwartz, D. and Kaufmann, D. (2020), "The relationship between innovation promotion processes and small business success: the role of managers' dominance”, Review of Managerial Science, Vol. ahead-of-print No. ahead-of-print, pp. 1-24, doi: 10.1007/s11846-020-00409-w.

Henseler, J., Ringle, C.M. and Sarstedt, M. (2015), "A new criterion for assessing discriminant validity in variance-based structural equation modeling", Journal of the Academy of Marketing Science, Vol. 43 No. 1, pp. 115-135.

Homburg, C., Klarmann, M. and Schmitt, J. (2010), "Brand awareness in business markets: when is it related to firm performance?”, International Journal of Research in Marketing, Vol. 27 No. 3, pp. 201-212.

Hoy, F., Perrigot, R. and Terry, A. (2017). "Research contributions to understanding franchising", in Hoy, F., Perrigot, R. and Terry, A. (Eds), Handbook of Research on Franchising, Edward Elgar Publishing, Cheltenham, pp. 1-16.

International Franchise Association (2021), "Economic outlook for franchising", available at: https://www. franchise.org/sites/default/files/2021-02/EconomicOutlook2021_web2.pdf (accessed 20 May 2021).

Jelenc, L., Pisapia, J. and Ivanusic, N. (2016), "Demographic variables influencing individual entrepreneurial orientation and strategic thinking capability", Journal of Economic and Social Development, Vol. 3 No. 1, pp. 3-16.

Kaur, P., Dhir, A., Talwar, S. and Ghuman, K. (2021), "The value proposition of food delivery apps from the perspective of theory of consumption value", International Journal of Contemporary Hospitality Management, Vol. 33 No. 4, pp. 1129-1159.

Khan, W.A., Hassan, R.A., Arshad, M.Z., Arshad, M.A., Kashif, U., Aslam, F. and Wafa, S.A. (2020), "The effect of entrepreneurial orientation and organisational culture on firm performance: the mediating role of innovation", International Journal of Innovation, Creativity and Change, Vol. 13 No. 3, pp. 652-677.

Kim, M.S., Thapa, B. and Holland, S. (2018), "Drivers of perceived market and eco-performance in the foodservice industry", International Journal of Contemporary Hospitality Management, Vol. 30 No. 2, pp. 720-739.

Lafontaine, F. and Slade, M. (2014), "Incentive and strategic contracting: implications for the franchise decision", in Chatterjee, K. and Samuelson, W. (Eds), Game Theory and Business Applications, Springer, NY.

Lawrence, P. and Lorsch, J. (1967), Organization and Environment, Harvard University Press, Cambridge MA.

Lopez-Bayon, S. and Lopez-Fernandez, B. (2016), "Partner empowerment and relationship failure in franchising", Journal of Small Business Management, Vol. 54 No. 4, pp. 1059-1079.

Lopez-Fernandez, B. and Lopez-Bayon, S. (2018), "Antecedents of early terminations in franchising: franchisor versus franchisee cancellations”, Small Business Economics, Vol. 50 No. 4, pp. 677-695.

Lumpkin, G.T. and Dess, G.G. (1996), "Clarifying the entrepreneurial orientation construct and linking it to performance", Academy of Management Review, Vol. 21 No. 1, pp. 135-172.

Lumpkin, G.T., Cogliser, C.C. and Schneider, D.R. (2009), "Understanding and measuring autonomy: an entrepreneurial orientation perspective", Entrepreneurship Theory and Practice, Vol. 33 No. 1, pp. 47-69.

Luqman, A., Talwar, S., Masood, A. and Dhir, A. (2021), "Does enterprise social media use promote employee creativity and well-being?”, Journal of Business Research, Vol. 131, pp. 40-54.

Martin, S.L. and Javalgi, R.G. (2016), "Entrepreneurial orientation, marketing capabilities and performance: the moderating role of competitive intensity on Latin American international new ventures", Journal of Business Research, Vol. 69 No. 6, pp. 2040-2051.

Mashovic, A. (2018), "Key financial and nonfinancial measures for performance evaluation of foreign subsidiaries", Journal of Contemporary Economic and Business Issues, Vol. 5 No. 2, pp. 63-74.
Revisiting the contingency theory 
McAdam, R., Miller, K. and McSorley, C. (2019), "Towards a contingency theory perspective of quality management in enabling strategic alignment", International Journal of Production Economics, Vol. 207, pp. 195-209.

Mishra, R. and Mishra, O.N. (2019), "Prioritising dimensions of entrepreneurial orientation for supply chain flexibility development in an uncertain environment", Journal of Manufacturing Technology Management, Vol. 30 No. 2, pp. 483-505.

Murillo Oviedo, A.B., Pimenta, M.L., Piato, E.L. and Hilletofth, P. (2020), "Development of marketoriented strategies through cross-functional integration in the context of the food and beverage industry”, Business Process Management Journal, Vol. 27 No. 3, pp. 901-921.

Nazarian, A., Atkinson, P. and Foroudi, P. (2017), "Influence of national culture and balanced organizational culture on the hotel industry's performance", International Journal of Hospitality Management, Vol. 63, pp. 22-32.

Nuvriasari, A., Ishak, A., Hidayat, A., Mustafa, Z. and Haryono, S. (2020), "The effect of market and entrepreneurship orientation on SME's business performance: the role of entrepreneurial marketing in Indonesian Batik industries", European Journal of Business and Management, Vol. 12 No. 5, pp. 29-37.

O'Cass, A. and Wetzels, M. (2018), "Contemporary issues and critical challenges on innovation in services", Journal of Product Innovation Management, Vol. 35 No. 5, pp. 674-681.

Otache, I. and Mahmood, R. (2015), "Entrepreneurial orientation and performance of Nigerian banks: the mediating effect of teamwork", Mediterranean Journal of Social Sciences, Vol. 6 No. 3, p. 406.

Pentina, I., Zhang, L., Bata, H. and Chen, Y. (2016), "Exploring privacy paradox in informationsensitive mobile app adoption: a cross-cultural comparison", Computers in Human Behavior, Vol. 65, pp. 409-419.

Podsakoff, P., MacKenzie, S. and Podsakoff, N. (2012), "Sources of method bias in social science research and recommendations on how to control it", Annual Review of Psychology, Vol. 63 No. 1, pp. 539-569.

Pugh, D.S., Hickson, D.J., Hinings, C.R. and Turner, C. (1968), "Dimensions of organization structure", Administrative Science Quarterly, Vol. 13, pp. 65-105.

Raju, V. and Phung, S.P. (2019), "Sustainability in performance management through supply chain management”, International Journal of Supply Chain Management, Vol. 8 No. 2, pp. 1085-1089.

Rauch, A. and Frese, M. (2006), "Meta-analysis as a tool for developing entrepreneurship research and theory", Advances in Entrepreneurship, Innovation, and Economic Growth, Vol. 9, pp. 29-51.

Rauch, A., Wiklund, J., Lumpkin, G. and Frese, M. (2009), "Entrepreneurial orientation and business performance: an assessment of past research and suggestions for the future", Entrepreneurship: Theory and Practice, Vol. 33, pp. 761-787.

Roberts, R.E., Frazer, L. and Thaichon, P. (2020), "A Western franchise in Shanghai, China: a late entrant's success", Journal of Strategic Marketing, Vol. ahead-of-print No. ahead-of-print, pp. 1-21, doi: 10.1080/0965254X.2020.1823457.

Rodriguez-Gutierrez, M.J., Moreno, P. and Tejada, P. (2015), "Entrepreneurial orientation and performance of SMEs in the services industry", Journal of Organizational Change Management, Vol. 28 No. 2, pp. 194-212.

Romero-Silva, R., Santos, J. and Hurtado, M. (2018), "A note on defining organisational systems for contingency theory in OM", Production Planning and Control, Vol. 29 No. 16, pp. 1343-1348.

Rosado-Serrano, A., Paul, J. and Dikova, D. (2018), "International franchising: a literature review and research agenda", Journal of Business Research, Vol. 85, pp. 238-257.

Sachdev, S.B. and Verma, H.V. (2004), "Relative importance of service quality dimensions: a multisectoral study", Journal of Services Research, Vol. 4 No. 1, pp. 94-116. 
Seth, H., Talwar, S., Bhatia, A., Saxena, A. and Dhir, A. (2020), "Consumer resistance and inertia of retail investors: development of the resistance adoption inertia continuance (RAIC) framework", Journal of Retailing and Consumer Services, Vol. 55, 102071.

Simpson, M., Padmore, J. and Newman, N. (2012), "Towards a new model of success and performance in SMEs", International Journal of Entrepreneurial Behavior and Research, Vol. 18, pp. 264-285.

Singh, G. and Slack, N.J. (2020), "New public management and customer perceptions of service quality-a mixed-methods study", International Journal of Public Administration, Vol. ahead-ofprint No. ahead-of-print, pp. 1-15, doi: 10.1080/01900692.2020.1839494.

Singh, G., Slack, N., Sharma, S., Mudaliar, K., Narayan, S., Kaur, R. and Sharma, K.U. (2021), "Antecedents involved in developing fast-food restaurant customer loyalty", The TQM Journal, Vol. ahead-of-print No. ahead-of-print, doi: 10.1108/TQM-07-2020-0163.

Slack, N., Singh, G. and Sharma, S. (2020), "Impact of perceived value on the satisfaction of supermarket customers: developing country perspective", International Journal of Retail and Distribution Management, Vol. 48 No. 11, pp. 1235-1254.

Song, S., Park, S. and Lee, S. (2019), "Does franchising reduce geographically diversified restaurant firms' risk?", International Journal of Contemporary Hospitality Management, Vol. 31 No. 1, pp. 161-179.

Stambaugh, J., Lumpkin, G.T., Mitchell, R.K., Brigham, K. and Cogliser, C. (2020), "Competitive aggressiveness, community banking and performance", Journal of Strategy and Management, Vol. 13 No. 2, pp. 221-240.

Tajeddini, K. and Trueman, M. (2016), "Environment-strategy and alignment in a restricted, transitional economy: empirical research on its application to Iranian state-owned enterprises", Long Range Planning, Vol. 49 No. 5, pp. 570-583.

Tajeddini, K., Martin, E. and Ali, A. (2020), "Enhancing hospitality business performance: the role of entrepreneurial orientation and networking ties in a dynamic environment", International Journal of Hospitality Management, Vol. 90, 102605.

Talwar, S., Dhir, A., Kaur, P. and Mantymaki, M. (2020a), "Barriers toward purchasing from online travel agencies", International Journal of Hospitality Management, Vol. 89, 102593.

Talwar, S., Dhir, A., Singh, D., Virk, G.S. and Salo, J. (2020b), "Sharing of fake news on social media: application of the honeycomb framework and the third-person effect hypothesis", Journal of Retailing and Consumer Services, Vol. 57, 102197.

Tandon, A., Kaur, P., Dhir, A. and Mäntymäki, M. (2020), "Sleepless due to social media? Investigating problematic sleep due to social media and social media sleep hygiene", Computers in Human Behavior, Vol. 113, 106487.

Thammasane, S. (2018), "The significance role of entrepreneurial orientation on the performance of food, beverage, and ice-cream franchises", 17th Global Business Research Conference, Tokyo, Japan.

Tsung-Chi, L., Chen, J.V. and Po-Yi, H. (2014), "Opportunity recognition and cooperation flexibility of entrepreneurial franchisees”, Industrial Management and Data Systems, Vol. 114 No. 4, pp. 506-525.

Van de Ven, A.H. (1976), "A framework for organization assessment", Academy of Management Review, Vol. 1, pp. 64-78.

Van de Ven, A.H. and Delbecq, A. (1974), "A task contingent model of work-unit structure", Administrative Science Quarterly, Vol. 19, pp. 183-197.

Watson, A. and Dada, L. (2017), "Managing entrepreneurial tensions in franchise systems", in Hoy, F., Perrigot, R. and Terry, A. (Eds), Handbook of Research on Franchising, Edward Elgar Publishing, Cheltenham, pp. 17-33.

Watson, A., Dada, L., Wright, O. and Perrigot, R. (2019), "Entrepreneurial orientation rhetoric in franchise organizations: the impact of national culture", Entrepreneurship Theory and Practice, Vol. 43 No. 4, pp. $751-772$.
Revisiting the contingency theory 
Watson, A., Dada, O., Lopez-Fernandez, B. and Perrigot, R. (2020), "The influence of entrepreneurial personality on franchisee performance: a cross-cultural analysis", International Small Business Journal, Vol. 38 No. 7, pp. 605-628.

Weaven, S., Baker, B.L., Edwards, C., Frazer, L. and Grace, D. (2018), "Predicting organizational form choice from pre-entry characteristics of franchisees", Australasian Marketing Journal (AMJ), Vol. 26 No. 1, pp. 49-58.

Weill, P. and Olson, M.H. (1989), "An assessment of the contingency theory of management information systems", Journal of Management Information Systems, Vol. 6 No. 1, pp. 59-85.

Williams, P., Ashill, N. and Naumann, E. (2017), "Toward a contingency theory of CRM adoption”, Journal of Strategic Marketing, Vol. 25 Nos 5-6, pp. 454-474.

\section{Corresponding author}

Samantha Naidu can be contacted at: samanthanaidu@yahoo.com

For instructions on how to order reprints of this article, please visit our website:

www.emeraldgrouppublishing.com/licensing/reprints.htm

Or contact us for further details: permissions@emeraldinsight.com 